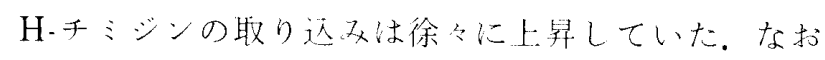
$\gamma$ - HuEPOそのものによるリンパ球幼若化は認好られ ず $\gamma$-HuEPOの mitogenic 作用は否定された。従って $\gamma$-HuEPOにて貧血が改善されることは患者免疫能に も強い影響を与兄るものと考克られた。

血液透析患者における h-ANP（心房性ナトリウム 利尿ペプチド) 測定の臨床的意義一D.W. (ドライウェ イト)設定の指標としての h-ANP一：桑原守正, 松下 和弘, 吉永英俊, 安芸雅史, 藤崎伸太(藤崎) 透析 患者に打けるD.W. の決定は浮腫の有無心胸郭比 (CTR)，血圧などを総合して決めるが，多分に経験的 な乎のでD.W．決定の指標がこ礼东でなかった。血中 HANP 濃度がその指標となるか否かを検討した。対 象：I 群健常者20名, II 群慢性腎不全(保存期) 18名, III群透析患者117名，G1心不全の西る者，G2心不全・ 高血玨のある者 8 名, G3高血圧のある者, G4合併症の ない者。方法：血中 HANP 濃度之透析期間, 年齢, CTR 等との相関抢よび透析による経時的变化を及た。 結果：血中 HANP は年齢・透析期間・腎機能の悪化と は相関せず除水により有意に低下する。IIIG4では CTRが50\%以上の者はそれ未満の者よりも有意に高 かった。結語：HANPは D.W. 決定の良い指標となり 完る。

\section{囊胞腎316例の臨床的検討：東原英二, 阿曽佳郎（東} 京大), 小磯謙吉（筑波大），伊藤晴夫（帝京大市原）, 酒井 紀 (慈恵大内科) 316名の常染色体優性遗伝の

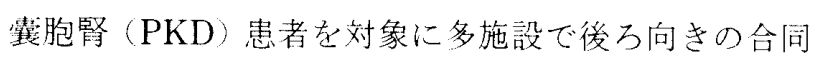
研究を㧍こなった。平均年齢 ( $51.4 \pm 13.3$ 歳), 診断時 年齢 $(44.5 \pm 13.5$ 歳) は男性（167名，内透析者42名） 上女性 (149名, 内透析者30名)の間に有意差はなかっ た。男女間腎機能，血圧，肝謷胞合併率 $(56.6 \%)$ ， 膵囊胞 $(7.1 \%)$, 脳動脈瘤 $(8.0 \%)$ 台併率の間に差は なかった。腎機能は年齢とともに低下し, 約 $1.1 \mathrm{ml} /$ $\mathrm{min} /$ 年の割合でクレアチニン・クリアランスは減少し ていた，60歳では平均 $23.5 \mathrm{ml} / \mathrm{min}$ になっておう，60歳 代で透析を受けている割合は約 $35 \%$ であった。肝囊胞 の合併者は, ない者より, 年齢, 血清 $\mathrm{Cr}, \mathrm{BUN}$ は有 意に高く, C cr は有意に低かった。肝震胞と膵囊胞の合 併には有意な相関が双られた。尿路感染症の睡往は女 性に多かった、以上, 本邦の PKDの特徵のいくつかを 明らかにした。

維持透析患者における手根管症候群の臨床的検討 一特にアミロイド沈着と手根骨X-Pにおける cystic radiolucency についてー: 橋本寛文, 井上善雄, 山下元
幸, 竹中 章, 湯浅健司, 寺尾尚民 (高知高須) 維

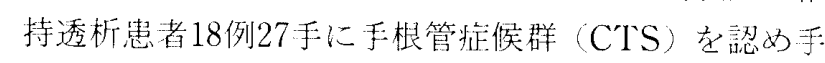
根管開放術を施行し, 手術時得られた横手根靸带の> ミロイド沈着性, 手根骨 X-Pでの cystic radiolucency (CRL)について検討した。手術時透析歴は136力月で あった。CRLを group 分類し, CTS との関係を子る之 group 4が 6 例10手と最も多いが, group 1も6 例 8 手

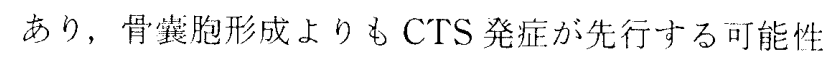
が示さ机た。アミロイド沈着は25手中17手に認められ， アルカリコンゴー赤, ダイロン染色での陽性部位が抗 的一マクログロブリン抗体による免疫染色で完全に 一致し, 抗 AA 抗体では全例陰性であったことより, これらのアミロイドの前駆タンパクが $\beta_{2}$-マイクログ ロブリンであることが証明された。

腎細胞癌組織の血小板活性化因子産生能についての 検討: 今川全晴, 高橋真一, 三股浩光, 谷川龍彦, 野 村芳雄, 緒方二郎 (大分医科大) 腎癌, 腎皮質抒よ び䯣質で血小板活性化因子 (PAF) 合成最終酵素であ る choline-phosphotransferase 活性を測定した。方 法: 腎癌患者13名の摘出標本上り得られた組織を破砕 後, 超遠心にて microsome t分離し, 1-Hexadenyl2-acetyl-sn-glycerol 及びCDP- $\left[{ }^{14} \mathrm{C}\right]$ choline と反応さ せた。 Bligh-Dyer 法で産物を抽出，TLCでPAFを分 離後, 放射活性を測定し, 酵素活性を定量した。結果, 考察： $\mathrm{Km}$ は62.5 $\mu \mathrm{M}, \mathrm{V} \max$ は7.04nmol $/ \mathrm{min} / \mathrm{mg}$ で 苛った。癌組織で $2.64 \pm 1.08 \mathrm{nmol} / \mathrm{min} / \mathrm{mg}$ protein,

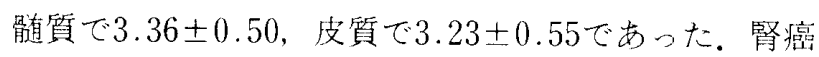
組織では high stage, factor $(+)$ で高い傾问にあり, PAF が腎癌の血行性転移や腫瘍塞栓形成に関与して いる可能性が示唆された。術前IFN 投与群で有意に低 く, IFN が腎癌のPAF 産生を抑制することが示唆さ れた。

Flow cytometryによる核内増殖関連抗原 p105と 核 DNA 量一腎癌における検討一: 横木広幸, 水谷雅

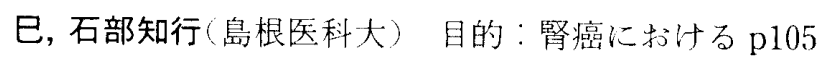
の発現を flow cytometryにて検討した。材料抢よび方 法：腎癌33例から得た76個のパラフィン包埋標から Hedley らの方法にて細胞を単離し, Epstein らの方法 による二重蛍光染色ののち FAC Star を用いて測定, two parameter 標示を行った. 結果：76検体中 DNA diploidy は23検体 (30\%) にみられた。 DNA diploidy 群において G2M 期で 105 蛍光強度が高く, G2M/ G0G1 fluorescence ratio は grade とともに上昇した。 ratioが2.20以上の割合はgrade $1 に$ 比し grade $2 て ゙$ 有 